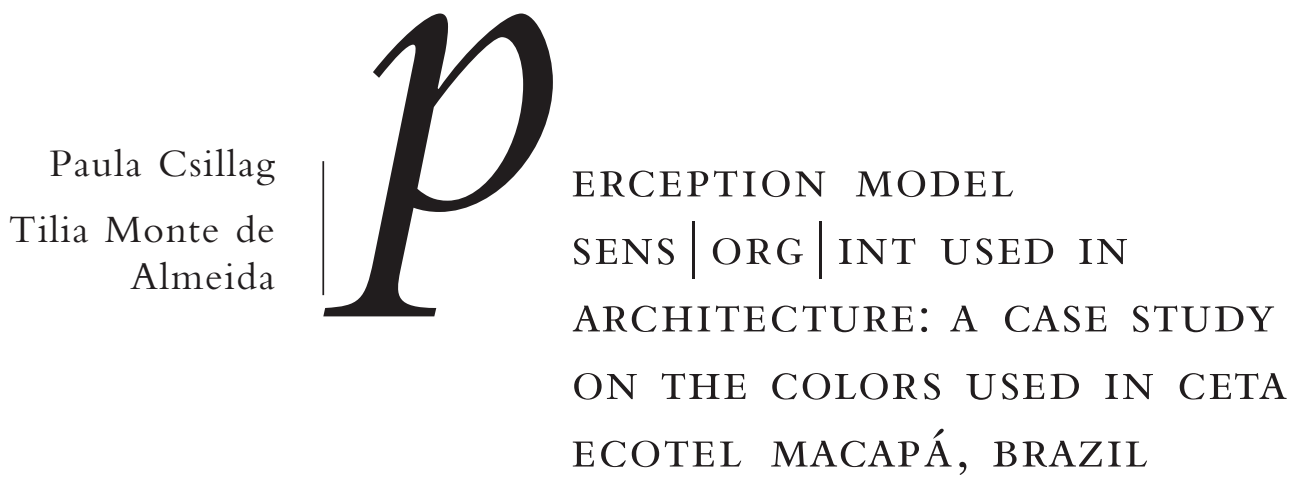

098

品

\begin{abstract}
The aim of this article is to present a study on how the use of colors on the internal and external architectural environments of a Brazilian hotel affected consumer behavior. The results are analyzed in terms of SENSIORGIINT Model, which differentiates physiological aspects of color human response from cultural and interpretive aspects (CSILLAG, 2008). The study was conducted at Ceta Ecotel, an ecological hotel at the city of Macapá on the northeastern coast of Brazil. The methodology was of a case study (YIN, 2004), using a triangulation process, crossing information obtained from three points of view: a qualitative \& quantitative questionnaire with 50 employees of the hotel, including the owners, a qualitative \& quantitative questionnaire with 640 guests of the hotel, and analyses of the data obtained using SENSIORGIINT Model of Perception. Results show consumers' most and least preferred colors for the environment. Results indicated reasons for the most and least preferred colors, presenting suggestions for future use of colors in architectural projects.
\end{abstract}

KeYwords

Color. Architecture. Perception. 


\section{O MODELO DE PERCEPÇÃO VISUAL SENS |ORG | INT USADO NA ARQUITETURA: UM ESTUDO DE CASO SOBRE CORES USADAS NO CETA ECOTEL MACAPÁ, BRASIL}

RESUMO

O objetivo deste artigo é apresentar um estudo sobre como o uso de cores em ambientes arquitetônicos externos e internos de um hotel brasileiro afetou o comportamento do consumidor. Os resultados são analisados em termos do Modelo SENSIORGIINT, que diferencia aspectos fisiológicos da resposta humana a cores, de fatores culturais e interpretativos (CSILLAG, 2008). O estudo foi conduzido no Ceta Ecotel, um hotel ecológico na cidade de Macapá no nordeste do Brasil. A metodologia foi de estudo de caso (YIN, 2004), usando um processo de triangulação, cruzando informações obtidas de três pontos de vista: um questionário qualitativo e quantitativo com 50 funcionários do hotel, incluindo os proprietários, um questionário qualitativo e quantitativo com 640 hóspedes do hotel e análise dos dados obtidos usando o Modelo de Percepção SENSIORGIINT. Os resultados indicam motivos para as cores mais e menos preferidas, apresentando sugestões para uso futuro de cores em projetos arquitetônicos.

Palavras-chave

Cor. Arquitetura. Percepção. 


\section{INTRODUCTION}

Color used in architectural projects many times are considered solely at the final steps, basically as decoration of external and/or internal environments. Some projects, though, have color as a central concept. This is the case of Ceta Ecotel, an ecological hotel at the northeastern coast of Brazil. This hotel was designed chromatically from its concept. Since it is a hotel, the end users are the hotel guests, thus, guests' color perception of the chromatic environments are indeed much valuable for the hotel's success. The color study here presented is related to the color perception at Ceta Ecotel, and may help analyze other chromatic architectural projects.

\section{VisUal PERCEPTION MODEL SENS|ORG|INT}

SENS|ORG|INT Model, was described in an article, awarded as the best submitted paper in IVLA's (International Visual Literacy Association) 2008 Book of Selected Readings (CSILLAG, 2009). The model differentiates the three processes that occur in human perception: sensory impressions, organizing processes, and interpretive processes of visual perception. This model takes into account psychological approaches to perception, both experimental as well as physiological, including findings on neuroscience, and unites these approaches to the traditional visual literacy approaches used in visual communication. With such a framework, applied to color, professionals dealing with colors, can differentiate concepts related to chromatic visual literacy valid as "laws" from those concepts that cannot be generalized to all human beings.

In the $19^{\text {th }}$ century, perception was studied as a passive stamping done by exterior stimuli on the retina. It would then reach the visual cortex, the zone of the occipital cortex that receives stimuli generated in the retina, resulting in an identical image (isomorphic) as the primary stimulus (CSILLAG, 2009).

Modern psychology refutes this notion and views perception as an active process that involves the search for corresponding information, the differentiation of essential aspects of an image, the comparison of these aspects with each other, the formulation of appropriate hypotheses and the comparison of these hypotheses with the original data (BRUNER, 1957; LEONTIEV, 1959; LURIA, 1981; VYGOTSKY, 1956, 1960; ZAPOROZHETS, 1967, 1968). Familiar and nonfamiliar images can be differentiated by longer or more contracted paths of perception (LURIA, 1981).

Telford (1970) differentiated sensation from perception in that the first comprises a simple conscience of the dimensions of experience, whilst perception implies the sensation and the meanings that are attributed to the experience. Thus, for this author, the determinants of perception are: context, constancy, distance, perspective, interposition, brightness, position, direction, accommodation, convergence motivation, emotion, and personality.

Theories about perception tend to emphasize the role of either sensory data or knowledge in the process (CSILLAG, 2009). Some theorists have adopt a datadriven or bottom-up stance, or synthetic approach, according to which perception is direct: visual data are immediately structured in the optical array prior to any selectivity on the part of the perceiver proposed by Hering (1878), Gestalt 
theories, and Gibson (1979). Others adopt a constructivist, top-down or analytical approach emphasizing the importance of prior knowledge and hypotheses, defended by Berkeley (1709), Helmholtz (1925), and Bruce, Green and Georgeson (2003).

The human brain has been studied in many details, and one way of organizing the study of different functions of the brain, was to divide it in areas. Thus, in terms of visual perception, the most important area is the visual cortex, consisting of the primary visual cortex (also called striate cortex or V1) and the extrasiate visual cortical areas, containing areas V2, V3,V4 and V5 (CSILLAG, 2012).

Visual analysis primarily takes place in the visual cortex, which is performed by specialized neurons (HUBEL; WIESEL, 1962, 1963). It has the influence of secondary zones of the visual cortex forming mobile syntheses of visually perceived elements under the modulating and regulating influence of other nonvisual zones of the cortex (LURIA, 1981).

Before synthesis can occur, the visual cortex must stabilize the image, because when the image reaches the retina, it lasts no longer than 1 to 1.5 seconds if the eye is not moving (YARBUS, 1965). Stabilization occurs by the formation of an after-image in the occipital zone that can last up to 20 to 30 seconds (ZIMKINA, 1957; KAPLAN, 1949).

In the 1970s Semir Zeki, with pioneering experiments in neuroscience, identified a small area of cells on each side of the brain that seemed specialized in responding to color. He named these V4. Processes of Primitive Vision considered bottom-up by neuroscientists, which are processes that do not require previous knowledge and are not determined by learning or experience, are the perceptions of movement, depth, form and color vision. Color can even be produced experimentally by a magnetic stimulus on V4 causing the "vision" of colored rings and halos, the so-called cromatophens (SACKS, 2003).

Recent findings in neuroscience have mapped the visual pathways (CHALUPA; WERNER, 2004; KNOBLAUCH; SHEVELL, 2004; PINNA; SPILLMAN, 2001; SHIMOJO; KAMITANI; NISHIDA, 2001; SPILLMAN; LEVINE, 1971; ZEKI, 2000) and have determined that perception occurs through a neural cascade, activating areas of the brain that are often very far apart. Thus, perception does not occur through isolated processes in the brain (CSILLAG, 2012).

\section{PROPOSED MODEL AND INVOLVED VARIABLES}

SENS|ORG|INT Model (Figure 1) differentiates three processes that occur in human perception: sensory impressions, organizing processes, and interpretive processes of visual perception (CSILLAG, 2009). The model was devised in an attempt to differentiate which concepts of visual communication tend to be common to all human beings with normal eyesight from the concepts that don't. Those that are not common therefore are learned or otherwise acquired. Therefore, this model unites the synthetic approach (HERING, 1964[1878]; GIBSON, 1979), and the analytical approaches (BERKELEY, 1709; HELMHOLTZ, 1925; BRUCE; GREEN; GEORGESON, 2003), neuroscientific explanations (CHALUPA; WERNER, 2004; KNOBLAUCH; SHEVELL, 2004; PINNA; SPILLMAN, 2001; SHIMOJO; KAMITANI; NISHIDA, 2001; SPILLMAN; 


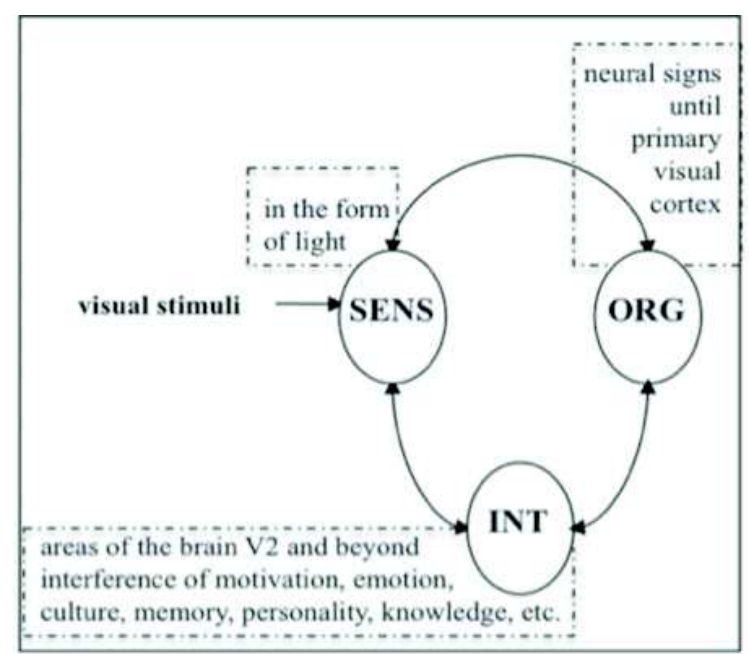

IO2
LEVINE, 1971; ZEKI, 2000) on how the brain works, and relates them to visual communication principles.

The variables intrinsic to the model are SENS (Sensory Impressions), ORG (Organizing Processes) and INT (Interpretive Processes), respectively explained below (CSILLAG, 2011). SENS variable (sensory impressions) is related to the sensory information received through the pupil in our visual sensory organ. This aspect of perception is a phenomenon that occurs in the eye only, still in the form of light, before it becomes neural signs in the retina.

ORG variable (organizing processes) is related to organizing aspects of perception that occur starting in the retina, including what is considered the primary visual cortex, mostly in area $\mathrm{V} 1$ of the striate cortex. Org is related to the bottom-up approaches of visual perception in psychology. The phenomena of perception that occur as Org are what tend to be considered as principles of visual communication.

INT variable (interpretive processes) refers to the elaboration of Org in the extrastriate visual cortex, including approximately areas V2, V3, V4 and V5 of the brain, and moving on to other areas of the brain. This variable refers to the topdown approaches to visual perception in psychology. It is in this moment of perception, that neural cascades occur, which undergo the interference of motivation, emotion, personality, culture, knowledge, etc. This aspect of perception causes variation and interpretation in design and in the proposed model, is called interpretive processes.

\section{Necessity of A Model}

It may be noted that different authors have different names and subdivisions for the same perceptive phenomenon (CSILLAG, 2009). For example, several authors (VYGOTSKY, 1956, 1960; BRUNER, 1957; LEONTIEV, 1959; ZAPOROZHETS, 1967, 1968; LURIA, 1981) have stated that perception refers to elements that fit in SENS, ORG and INT, whilst other authors (KRECH; CRUTCHFIELD, 1976; WHITTAKER, 1977; TELFORD, 1970) have stated that SENS is called sensation, and perception is related to ORG and INT only. Also, it is noted that Telford actually unites ORG and INT when he presents the determinants of perception as being: context, constancy, distance, perspective, interposition, brightness, position, direction, accommodation, convergence, motivation, emotion and personality; all of these refer to ORG except for the last three (motivation, emotion and personality), which refer to INT.

Another reason for the necessity of the present model is to unite different approaches in one stance. In psychology, for instance, there are the analytical or top-down approaches versus the synthetic or bottom-up approaches. These approaches are not, in fact, against each other, but they are complementary and if put together in one model, we get a better understanding of visual perception. 
The present model may also be significant in uniting different fields of study, such as psychology, neuroscience and visual communication. These fields classically refer to visual perception, sometimes referring to it in an informal way, other times in a very technical way. The proposed model intends to unite these fields in such a way that it can be of use for visual communicators, having objective scientific data as its theoretical basis.

One of the main reasons the model is necessary is to differentiate the elements of visual perception that tend to be common to all human beings from those that don't. This is of particular importance in identifying which aspects of perception can be considered as visual communication principles that tend to be valid for everyone and what cannot be generalized to all human beings. With such a model, teachers, researchers and practitioners can have a framework to work with so the different aspects of perception would not be intertwined, which happens more often than we would wish.

For example, one confusion between ORG and INT can be seen in color design principles, referring to the color light green. Itten (1979) correctly stated that this is a calming and soothing color. He even cited an example of racing horses that were put in stables painted in this color, compared to horses put in stables painted red, right after the race. The first had their blood pressure lowered in a shorter period of time, compared to the latter, which had their blood pressure remain high during a longer period of time. Itten's description of green is purely ORG, as it is exclusively physiological.

Now, it is frequent to see this same green color in art and design books or posts, characterizing it an elegant or delicate color. These adjectives do not relate to physiological processes and therefore cannot be considered ORG. They are INT and should not be generalized to all human beings.

\section{RELATIONSHIPS BETWEEN ORG AND INT}

One very important observation about the proposed model refers to the relationships between ORG and INT: INT is majorly determined by the spectrum of possibilities proposed by ORG. Figure 2 (A and B) illustrates this, whereas, Figure 2A shows lines in a static composition, whereas Figure 2B shows a dynamic composition. Each of the two compositions may be interpreted using positive or negative connotations. For example, the static composition may be interpreted as boring (negative) or serene (positive). The dynamic one, may be interpreted as confusing (negative) or joyful (positive). The static and dynamic aspects of each scheme are related to organizing processes of the brain (ORG) and the interpretations of the composition being serene or joyful are all INT. Now the important thing to note here is that Figure 2A tends to not being perceived as joyful, nor does Figure $2 \mathrm{~B}$ tend to be regarded as serene. This shows the importance of ORG in determining basic visual literacy skills (CSILLAG, 2015).

\section{Method}

This study was conducted at Ceta Ecotel, an ecological hotel at the city of Macapá on the northeastern coast of Brazil. This hotel was chosen since it was designed chromatically, and had the colors of the architecture of each guest house chosen 
Figure 2: Stactic (left [A]) and Dynamic (right $[\mathrm{B}]$ ) Compositions Source: (CSILLAG, 2015, p. 23 and 24).

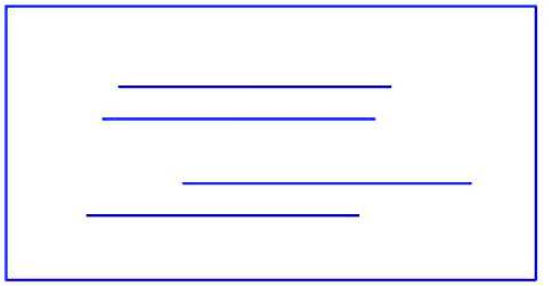

A

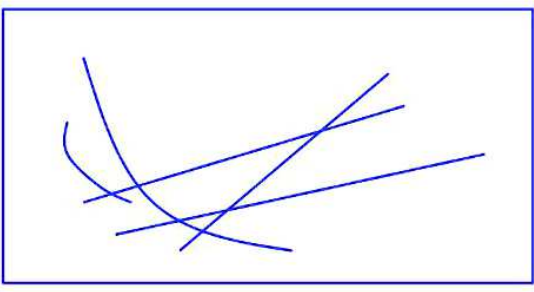

B purposely for identification. The methodology was of a case study (YIN, 2004), using a triangulation process, crossing information obtained from three points of view: a qualitative \& quantitative questionnaire with 50 employees of the hotel, including the owners, a qualitative \& quantitative questionnaire with 640 guests of the hotel, and analyses of the data obtained using SENS|ORG|INT Model of Perception, together with the researchers' analysis of the environment.

The studied population in this research was of Brazilian guests of this particular hotel, which is a population that may be considered, statistically, infinite. A statistic sample of this population was defined in order to represent this population, using the formula, $n-\left(\sigma^{2} \times p \times q\right)+e^{2}$ (LEVINE; STEPHAN; KREHBIEL; BERENSON, 2002), whereas, $n$ is the size of the sample; $\sigma^{2}$ is the chosen confidence level, expressed in number of standard deviations; $p$ is the percentage in which the phenomenon occurs; $q$ is the complementary percentage (100-p); and $e$ is the maximum error permitted.

For this research, the chosen confidence level was $95 \%$, corresponding to two standard deviations, with a maximum error of $3 \%$, while $p$ is $90 \%$. These numbers present a sample number of $n=400$. The period of this research lasted two months, period in which the researchers had access to 640 guests, thus covering the needed sample. For the staff of the hotel, there was no need to calculate a sample, because all the staff was contacted, being the number of 50 subjects, $100 \%$ of the staff population.

During this period, all the guests were Brazilians, thus eliminating the variable of international culture in terms of influences on color interpretative processes. Thus the results could only be inferred for the studied population of Brazilian guests for this hotel. Of the studied sample, 53\% were male and $47 \%$ were female, with ages ranging from 35 to 57 years.

\section{RESULTS AND DISCUSSION}

The hotel consists of 20 separate guest houses each of which colored externally and internally with one of eight colors. Also, not only colors are used internally on the walls, but also on the beddings, curtains, blankets and decoration elements. The questionnaires that were applied to guests were analyzed and illustrated guests' most and least preferred colors for the environment as well as the guests' associations to each color.

The quantitative questions of the questionnaire were analyzed in charts. Apart from the quantitative questions, qualitative questions addressed guests' preferences and associations with certain colored environments. The researchers used the SENS|ORG|INT framewok to further analyze the results obtained from 
Photographed with Permission by Tilia Monte, at Ceta Ecotel, Rua do Matadouro, 640,

Macapá, Amapá, 68911-080, Brazil.

2 Photographed with Permission by Tilia Monte, at Ceta Ecotel, Rua do Matadouro, 640, Macapá, Amapá, 68911-080, Brazil.

3 Photographed with Permission by Tilia Monte, at Ceta Ecotel, Rua do Matadouro, 640,

Macapá, Amapá, 68911-080, Brazil. the questionnaires. This framework offers the possibility of understanding the origins of the color preferences, if physiological or cultural/learned, triangulated with questionnaire responses.

Results showed that the preferred colors for guest houses, according to guests' preferences and rates of occupation were, green, blue, and white, whereas white and green had $100 \%$ of satisfaction, while blue had $80 \%$ satisfaction. Table 1 shows the percenteages of preferred colors. Figures 3, 4 and 5, show the preferred guest houses.

Questionnaires showed the associations that guests mentioned to each color. For the color blue, $80 \%$ of guests mentioned that they associated the blue color of this hotel with water, $80 \%$, with sky, $80 \%$ with calmness, $80 \%$ with relaxation, $20 \%$ with freshness and 20\% with sadness. For the green color used in this hotel, $80 \%$ of guests associated it with water, $80 \%$ with plants, $60 \%$ with calmness, $60 \%$ with relaxation, and $40 \%$ with freshness. For the achromatic color white, $80 \%$ of guests associated its use in this hotel to cleanliness, and $20 \%$ to calmness.

SENS|ORG|INT Model was used to further analyze these results, helping to understand the reasons for each color preference, as well as helping to understand the reasons for each association. The ORG aspect of the preferred colors green and blue helps to explain why they were preferred; it is noted that they are colors that are physiologically calming (white here is considered achromatic but still considered calming since it is not arousing). There is evidence of excitatory and inhibitory features of channels $r-g$ and $y-b$. These excitatory and inhibitory features were revealed as increases and decreases in ordinary vital signs (e.g. blood pressure, oxygen uptake, heart and breathing rates), alpha wave activity, galvanic skin response, the effect on hyperbilirubinemia (jaundice), the frequency of eye blinks and epileptic seizures, among others (KAISER, 1996). Therefore, there is evidence of direct physiological connections between seeing green/blue and feeling calmer (CSILLAG, 2013).

Other authors (MAHNKE, 1996) also confirm the inhibitory features of blue and green. Gerard (1957) found that the color red had a more
Table 1: Preferred Colors for Guest Houses. Source: Elaborated by the authors.

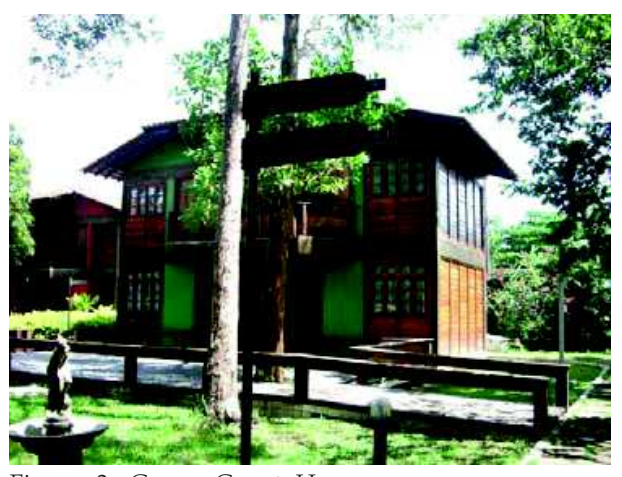

Figure 3: Green Guest House. Source: Authors' photo $^{1}$.

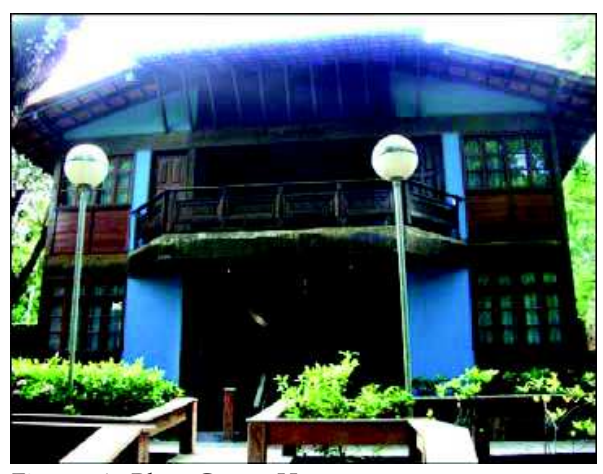

Figure 4: Blue Guest House Source: Authors' photo $^{2}$

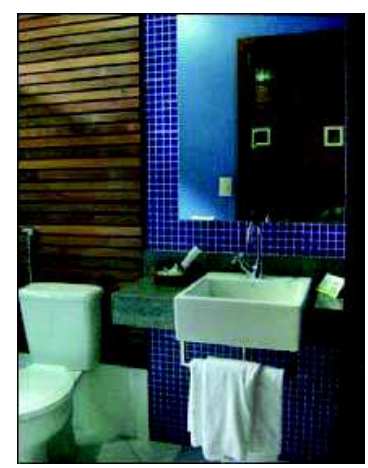

Figure 5: Indoor Decoration of Blue Guest House. Source: Authors' photo $^{3}$. 
${ }^{4}$ Photographed with Permission by Tilia Monte, at Ceta Ecotel, Rua do Matadouro, 640, Macapá, Amapá, 68911-080, Brazil.

5 Photographed with Permission by Tilia Monte, at Ceta Ecotel, Rua do Matadouro, 640,

Macapá, Amapá, 68911-080, Brazil.

${ }^{6}$ Photographed with Permission by Tilia Monte, at Ceta Ecotel, Rua do Matadouro, 640, Macapá, Amapá, 68911-080, Brazil. arousing effect than did blue on the visual cortical activity and in functions of the autonomic nervous system. Ali (1972), using electroencephalogram analysis, demonstrated greater arousal following red light than blue light. Frieling (1990) reported an experiment where subjects were asked to look into red, yellow, green and blue light. Their comments were tape-recorded and presented in accordance with Wundt's 'wind rose of emotions'. He also observed the subjects' behaviour in terms of twitching, moving. The windrose separates emotions into categories of arousing-calming, pleasant-unpleasant, tension-release. For blue, he reported as calming and pleasant.

Analysis of the color associations of the preferred colors, in terms of SENS|ORG|INT Model shows that the association of blue and green with calmness and relaxation are derived of the fact that blue and green are physiologically calming colors, due to their ORG aspect. Other associations with blue like, water, sky and freshness are interpretive, meaning they belong to INT variable of SENS|ORG|INT Model, thus being cultural or learned in some way. The observed associations of blue and green to water, sky and freshness are INT associated with nature. The observed associations of white to cleanliness is INT
I06

: associated to lack of dirt. Therefore, two of the most preferred colors, blue and green, in terms of ORG variable, are physiologically calming. Since Ceta Ecotel is a tourism hotel, a calming environment, suggesting relaxation for the guests is indeed efficient.

SENS|ORG|ING model further helps to explain the most preferred colors in terms of INT, referring to color associations. Results of questionnaires showed that the guests' associations for the colors blue and green strongly referred to nature: water, sky (blue); water, plants (green). Since Ceta Ecotel is an ecological hotel, in the middle of the Amazon rainforest, the use of colors that promote these associations are also efficient, suiting the intent of this environment.

On the other hand, there were other guest houses that were not as efficient chromatically (Figure 6, 7 and 8). Results showed that the least preferred colors for guest houses, according to guests' preferences were purple, orange and red, whereas these three

Table 2: Least Preferred Colors for Guest colors had, each $80 \%$ of insatisfaction (Table 2). These guest houses were also the least occupied by guests, due to guest choices.

Source: Elaborated by the authors.

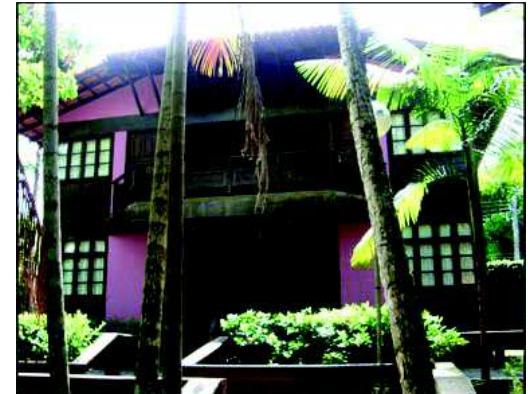

Figure 6: Purple Guest House. Source: Authors' photo ${ }^{4}$.

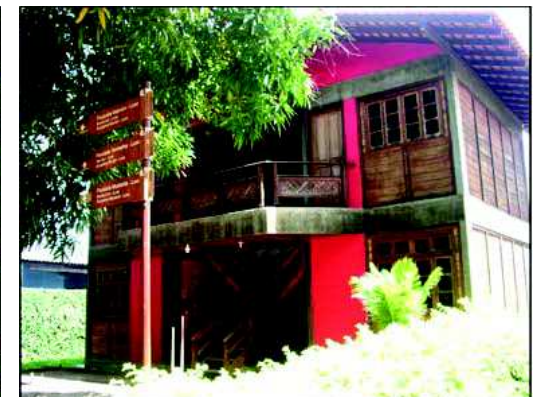

Figure 7: Red Guest House. Source: Authors' photo $^{5}$.

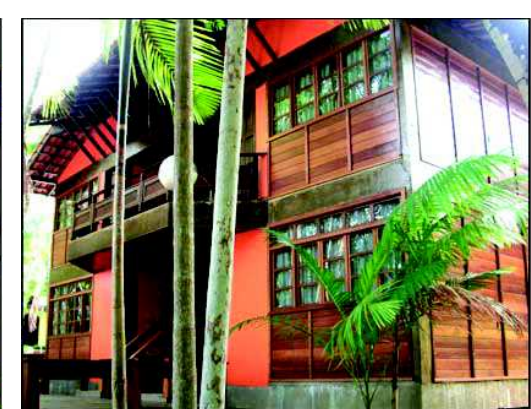

Figure 8: Orange Guest House. Source: Authors' photo $^{6}$ 
Analyzing the Org aspect of two of the least preferred colors (red and orange) helps to understand why they were the least preferred. It is noted that they are colors that are physiologically arousing. As mentioned above, there is evidence of excitatory and inhibitory features of channels $r-g$ and $y-b$. These excitatory and inhibitory features were revealed as increases and decreases in ordinary vital signs (e.g. blood pressure, oxygen uptake, heart and breathing rates), alpha wave activity, galvanic skin response, the effect on hyperbilirubinemia (jaundice), the frequency of eye blinks and epileptic seizures, among others) (KAISER, 1996). Therefore, there is evidence of direct physiological connections between seeing red/yellow and feeling more agitated (CSILLAG, 2013).

Other authors (MAHNKE, 1996) also confirm the excitatory features of red and orange. As mentioned, Gerard (1957) found that the color red had a more arousing effect than did blue on the visual cortical activity and in functions of the autonomic nervous system. Ali (1972), using electroencephalogram analysis, demonstrated greater arousal following red light than blue light. Frieling (1990) reported an experiment where subjects were asked to look into red, yellow, green and blue light. Their comments were tape-recorded and presented in accordance with Wundt's 'wind rose of emotions'. He also observed the subjects' behavior in terms of twitching, moving. The windrose separates emotions into categories of arousing-calming, pleasant-unpleasant, tension-release. He found for red, and increase in pulse and uneasiness. Gerbert (1977) had four rooms painted in red, yellow, green, blue respectively. Physiological measurements showed definite and constant results only for the red room, as an increase in arousal.

The associations mentioned by guests via questionnaires for the color red used in this hotel were that, $100 \%$ of guests associated the color with blood, 100\% with fire, and $80 \%$ with agitation. For the color orange, $80 \%$ of guests associated it with agitation, $80 \%$ with fire, $20 \%$ with sun, and $20 \%$ with summer. For the color purple, $80 \%$ of guests associated it with sadness, $60 \%$ with shadow, and $40 \%$, with rain.

Analysis of the color associations of these least preferred colors, in terms of SENS|ORG|INT Model shows that the association of red and orange with agitation are derived of the fact that red and orange are physiologically arousing, due to its ORG aspect. Other associations with red were: blood and fire, both interpretive, meaning they belong to INT variable of SENS|ORG|INT Model, thus being cultural or learned in some way. Observed associations of the color orange with fire, sun and summer are INT associated with nature. Observed associations of purple to shadow and rain are INT associated with aspects of nature.

Therefore, two of the least preferred colors, red and orange, in terms of ORG variable, are physiologically arousing. Being this hotel a place intended for vacation and relaxation, the use of red and orange for these guest houses proved to be inefficient, causing discomfort on guests.

Considering INT aspects of the least preferred colors, associations mentioned by guests, red and orange were mainly associated with blood and fire, associations which do not suit a relaxing hotel environment, thus helping to explain red and orange being least preferred. The association of purple with shadow and sadness do not suit an environment that people choose for vacations and enjoyment. 
It is important to note here the importance of the shade of each color used. For example, the shade of green could be more bluish, which would create a more calming environment, in terms of ORG, and the association (INT) would probably be more associated with water. Rather, if the shade of green were more yellowish, the INT association would probably be more more linked with budding plants. A darker shade of green, would probably show an INT association more associated to trees or forests.

Neverheless, they are all green, highlighting the importance of not generalizing names of colors with certain associations. Most of all, the associations with each color should always be analyzed for each individual case, as was with the shades of each color used at Ceta Ecotel.

Additional results of qualitative questionnaires showed some important issues on the use of colors in hotels. Questionnaires with owners showed that the reason for using different colors for each guest house was as a means of more easily identifying each different guest house. The decision was made by the owner, an engineer that simply liked colors. Questionnaires with employees and owners revealed in many forms the idea that the use of colors has a positive impact on the hotel's consumer perception. Some phrases collected were: "The use of colors strengthens our brand,"; "The guests always comment positively on the use of the colors. They see it as very creative."

\section{Conclusions}

Concluding this study, results showed that the preferred colors for guest houses, according to guests' preferences and rates of occupation, were green, blue and white. These results were triangulated for analysis using SENS|ORG|INT Model indicating that visitors preferred colors that have a calming and relaxing physiological response in terms of ORG variable. Since Ceta Ecotel is a tourism hotel, a calming and relaxing environment is preferred, thus colors should be used with this intent. SENS|ORG|ING model further helped to explain the most preferred colors in terms of INT, referring to color associations. Results of questionnaires showed that the guests' associations for the colors blue and green strongly referred to nature: water, sky (blue); water, plants (green). Since Ceta Ecotel is an ecological hotel, in the middle of the Amazon rainforest, the use of colors that promote these associations are also efficient, suiting the intent of this hotel with its specific market niche, an ecological hotel. The achromatic color white, in terms of ORG, is considered not arousing and in terms of INT was associated by guests to cleanliness. Of the least preferred colors, red and orange, in terms of ORG variable, are physiologically arousing. Being this hotel a place intended for vacation and relaxation, the use of red and orange for these guest houses proved to be inefficient, causing discomfort on guests. Considering INT aspects of the least preferred colors, associations mentioned by guests for the colors red and orange were mainly associated with blood and fire, associations which do not suit a relaxing hotel environment, thus helping to explain why the colors red and orange were least preferred. The color purple also did not suit guests that mentioned this color as associated with shadow and sadness, associations which are not related to an environment of vacations and enjoyment. 
These results confirm aspects of environmental color design (CAIVANO, 2006; SCHINDLER, 2005; KWALLEK; SOON; LEWIS, 2007; KÜLLER; MIKELLIDES; JANSSENS, 2009) addressing the importance of color on environmental design, not as a complement of the architectural process, but instead as a primary design issue. SENS|ORG|INT framework helped to understand the preferences and color associations that guests had in this case study, differentiating aspects of colors that are physiological from aspects that are learned or cultural. These analyses bring parameters that may orient future architectural projects. SENS|ORG|INT Model helps to understand different aspects of the use of colors, being useful, with empirical information as this case study, for future architectural projects.

\section{REFERENCES}

ALI, Mark. Pattern of EEG Recovery Under Photic Stimulation by Light of Different Colors. Electoencephalography Clinical Neuropshysiology 22: 332-35. 1972.

BERKELEY, George. Berkeley Selections. New York: Scribner's, 1929 [1709].

BRUCE, Vicki; GREEN, Patrick; GEORGESON, Mark. Visual perception. Hove: Psychology Press, 2003. BRUNER, Jerome. On Perceptual Readiness. In Psychol. Rev., Vol. 64, No. 2, 1957.

CAIVANO, Jose. Luis Research on Color in Architecture and Environmental Design: Brief History, Current Developments, and Possible Future. Color Research and Application. Vol.31, no. 4, 2006. CHALUPA, Leo; WERNER, John. (Eds.). The visual neurosciences. Cambridge: MIT Press, 2004. CSILlAG, Paula. A Model of Visual Perception Useful for Designers and Artists. In: Griffin, R.; D'averignou, M. (Org.). Visual Literacy Beyond Frontiers: Information, Culture and Diversity. Loretto: St. Francis University Press, v., p. 11-20, 2008.

CSILLAG, Paula. A Model of Visual Perception Useful for Designers and Artists. Journal of Visual Literacy, v. 28, p. 127-146, 2009.

CSILLAG, Paula. Comunicação Com Cores. São Paulo: SENAI SP, 2015.

CSILLAG, Paula. Food package chromatic design: A case study applying model Sens-Org-Int. Journal of the International Colour Association, v. 10, p. 37, 2013.

CSILLAG, Paula. Um mapeamento de estudos de cores frente ao Modelo SENS|ORG|INT de percepção visual de modo a identificar princípios cromáticos que tendem a ser generalizáveis aos seres humanos. Infodesign (SBDI. Online), v. 8, p. 39-47, 2011.

CSILLAG, Paula. Relationships between Neuroscience and visual perception model Sens-Org- Int contributing to Design practices. In: FARIAS, Priscila Lena; CALVERA, Anna; BRAGA, Marcos da Costa; SCHINCARIOL, Zuleica (Eds.). Design frontiers: territories, concepts, technologies [ICDHS 2012 - 8th Conference of the International Committee for Design History \& Design Studies]. São Paulo: Blucher, 2012. p. 386-390

FRIELING, Heinrich. Gesetz der Farbe. Gottingen: Muster-Schmidt Verlag, 1990.

GERARD, Robert. The Differential Effects of Lights on Physiological Functions. Ph.D. Diss., University of California, Los Angeles, 1957.

GERBERT, Frank. Pshychologische und Physiologische Wirkungen von Umgebungsfarben. PhilipsUniversitat, Marburg, 1977.

GIBSON, James. The Ecological Approach To Visual Perception. Boston: Houghton-Mifflin, 1979.

HELMOLTZ, Hermann. Treatise on physiological optics: The perceptions of vision. Optical society of America, Ithaca, 1925.

HERING, Ewald. An Outline of a Theory of the Light Sense. Cambridge: Harvard University Press, 1964 (1878)

HUBEL, David; WIESEL, Torsten. Receptive Fields, Binocular Interaction And Functional Interaction and Functional Architecture Of The Cat's Visual Cortex. In J. Physiol. Vol. 106, 1962.

HUBEL, David; WIESEL, Torsten. Receptive Fields Of Cells In Striate Cortex Of Very Young, Visually 
Inexperienced Kittens. In J. Neurophysiol., Vol. 26, 1963.

ITTEN, Johannes. The Art Of Color. New York: John Wiley \& Sons, 1979.

KAISER, Peter; BOYNTON, Robert. Human color vision. Washington DC: Optical Society of America, 1996.

KAPLAN, Albert. Visual After-Images In Cases Of Disturbance Of The Normal Activity Of The Central Nervous System. Moscow: Acad. C\&L, 1949.

KNOBLAUCH, Kevin; SHEVELL, Stuart. Color appearance. In Chalupa, L. \& Werner, J. (Eds.). The visual neurosciences. Cambridge: MIT Press, 2004.

KRECH, D.; CRUTCHFIELD, R. Elementos de Psicologia. São Paulo: Ed. Pioneira, 2 vol., 1976.

KÜLLER, Rikard; MIKELLIDES, Byron. and JANSSENS, Jan. Color, arousal, and performance-A comparison of three experiments. Color Research and Application, 34: 141-152, 2009.

KWALLEK, Nancy; SOON, Kokyung; LEWIS, Carol. Work Week Productivity, Visual Complexity, and Individual Environmental Sensitivity in Three Offices of Different Color Interiors. Color Research and Application. Vol.32, no. 2, 2007.

LEONTIEV, Aleksei. Problems In Mental Development. Moscow: Izd. Akad., 1959.

LEVINE, David; STEPHAN, David; KREHBIEL, Timothy; BERENSON, Mark. Statistics for Managers Upper Saddle River: Prentice Hall, 2002.

LURIA, Alexander Romanovich. Fundamentos De Neuropsicologia. Rio De Janeiro: Ed. Da Universidade De São Paulo, 1981.

MAHNKE, Frank. Color, Environment \& Human Response. New York: John Wiley \& Sons, 1996

PINNA, Baingio; SPILLMAN, Lothar. Surface Color From Boundaries: a new watercolor illusion. Vision Research, 41, 2669-2676, 2001

SACKS, Oliver. Um Antropólogo Em Marte. São Paulo: Cia. Das Letras, 2003.

SCHINDLER, Verena. Colour as vocation: Werner Spillmann's contribution to environmental colour design. Color Research and Application, 30: 53-65, 2005.

SHIMOJO, Shinsuke; KAMITANI Yukiyasu; NISHIDA Shin'ya. Afterimage of perceptually filled-in surface. Science. Aug 31;293(5535):1677-1680, 2001.

SPILLMANN, Lothar; LEVINE, Joel. Contrast enhancement in a Hermann grid with variable figureground ratio. Experimental Brain Research, 13: 547-559, 1971.

TELFORD, Charles. Psicologia. São Paulo: Cultrix, 1970.

VYGOTSKY, Lev. Selected Psychological Investigations. Moscow: Izd. Akad, 1956.

VYGOTSKY, Lev. Development Of The Higher Mental Functions. Moscow: Izd. Akad., 1960.

WHITTAKER, J. Psicologia. Rio De Janeiro: Ed. Interamericana, 1977.

YARBUS, Al'fred Luk'yanovich. Eye Movements And Vision. New York: Plenum Press, 1965.

YIN, Robert. Estudo de Caso. Planejamento e Métodos. $3^{\text {a }}$ ed. Porto Alegre: Bookman, 2004.

ZAPOROZHETS, Alexander. Perception And Action. Moscow: Prosv. Press, 1967.

ZAPOROZHETS, Alexander. Formation Of Perception In The Preschool Child. Moscow: Prosv. Press, 1968.

ZEKI, Semir. The architecture of the colour centre in the human visual brain: New results and a review. European Journal Of Neuroscience 12 (1), 172-193, 2000.

ZIMKINA, Anna Mikhailovna. Some Special Features Of Tactile Trace Processes (After Images) In Man. Moscow: Izd. Acad, 1957. 


\section{Author's note}

The origin of this research was conducted and financed by CAEPM|ESPM, and the presentation at AIC2016 had the kind support of ESPM Design Graduation Course, CAEPM and ProCor.

Editor's note

Submitted: 03/03/2017

Acceptance: 05/21/2017

English revision: Paula Csillag

\section{Paula Csillag}

Faculty of Design. ESPM University. São Paulo, SP.

CV: http://lattes.cnpq.br/5541357709140207

paula@publishing.com.br

\section{Tilia Monte de Almeida}

São Paulo Fine Arts University. São Paulo, SP.

CV: http://lattes.cnpq.br/7210935858209425 